\title{
Study Circles in Online Learning Environment in the Spirit of Learning-Centered Approach
}

\author{
Szilvia Simándi* \\ Received: April 8, 2017; received in revised form: June 26, 2017; \\ accepted: July 1, 2017
}

\begin{abstract}
:
Introduction: In the era of information society and knowledge economy, learning in non-formal environments gets a highlighted role: it can supplement, replace or raise the knowledge and skills gained in the school system to a higher level (Forray \& Juhász, 2008), as the so-called "valid" knowledge significantly changes due to the acceleration of development. With the appearance of information technology means and their booming development, the possibilities of gaining information have widened and, according to the forecasts, the role of learning communities will grow.

Purpose: Our starting point is that today, with the involvement of community sites (e.g. Google+, Facebook etc.) there is a new possibility for inspiring learning communities: by utilizing the power of community and the possibilities of network-based learning (Ollé \& Lévai, 2013).

Methods: We intend to make a synthesis based on former research and literature focusing on the learning-centered approach, online learning environment, learning communities and study circles (Noesgaard \& Ørngreen, 2015; Biggs \& Tang, 2007; Kindström, 2010)

Conclusions: The online learning environment can be well utilized for community learning. In the online learning environment, the process of learning is built on activity-oriented work for which active participation, and an intensive, initiative communication are necessary and cooperative and collaborative learning get an important role.
\end{abstract}

Key words: study circle, online learning environment, learning-centered approach.

\section{Introduction}

Recently, lifelong learning validation is getting into the focus of attention both in the world of work and training. From the point of view of validation/recognition, we can distinguish between formal (identified with school system training) and all the other learning environments. In the most general sense, validation serves the "visualization" of the gained knowledge. In this approach, it is the result of learning that is important, i.e. the result is important and not the environment in which learning takes place. Participation in courses organized in the training market, work experience, participation in open courses, or self-study can serve as examples of learning environments different from the formal one. Thereby, there is an opportunity to certify such gained, but not

Szilvia Simándi, Eszterházy Károly University, Eger, Hungary; simandi.szilvia@uni-eszterhazy.hu 


\section{Acta Educationis Generalis \\ volume 7, 2017, issue 2}

documented learning results by their validation in the labour market or in different trainings.

The learning-oriented approach builds on the active involvement of the participants, putting the community and knowledge into focus, and strengthens the learning process by helping, supporting evaluation. The learning-oriented approach is strengthened also by the expectations of the labour market where practice-oriented, activity-based learning situations are getting to be appreciated.

On the basis of Kopp's (2013) work, the pillars of the learning-oriented approach can be summarized as follows:

- Learner-orientation: Builds on different preliminary knowledge of the participants, their different learning needs, and it is characterized by flexible and diverse learning management.

- Knowledge orientation: It is problem-oriented and practice-oriented, learning is active, activity-based and situational.

- Helping, supporting evaluation: Formative evaluation is getting more and more emphasized, i.e. it promotes learning by evaluation during the learning process.

- Community orientation: Builds on cooperation and learning from each other (Biggs \& Tang, 2007).

In this paper, we are looking for the similar features between the learning-oriented approach and study circles, with special attention to the possibilities of study circles to be realized in the online learning environment.

The aim of this paper is not to show the study circle initiative in its detailed history, we only emphasize some stations in a nutshell. So, in the introduction of study circles, we focus on certain pillars of the learning-oriented approach.

The first study circle, which can be connected to self-organizing education characteristic for Swedish adult learning, was established by Oscar Olsson (1877-1950), a university student in Lund, near Malmö, in 1902. At the beginning of the 20th century, the target groups of the non-formal adult education were the disadvantaged groups, in case of which the primary aim was to increase the qualification level. The members of the study circles held their meetings in flats, churches, schools, rented rooms etc., in private circles. Besides increasing knowledge, the aim was to strengthen self-confidence so that the participants would be able to change their situations by their own efforts. Study circles are still popular in Sweden; they have become a part of the natural lifestyle of the Swedish population. Study circles are based on common interests and volunteering: the participants regularly learn in communities on the basis of their common interests. Olof Palme, the former Prime Minister of Sweden, regarding study circles once said, "Sweden is a Study Circle democracy to a great extent" (Harangi, 2010, pp. 32-33). In 2008, 1.9 million participants spent 9.8 million learning hours in 275,000 study circles, it means that each participant studied an average of 36 hours in a study circle. This complies with such a typical study circle that sits together for a 3-hour activity at about 10 times (Kindström, 2010, p. 50).

The practices of the Swedish study circles have spread to many countries, although they have a different name, practices and history in each country (see Australia: Australian Study Circles Network; Bangladesh: Study Circle Bangladesh; Canada: Study circles A guide for programmers; Sweden: The Swedish National Council for Adult Education, The Swedish Adult Education Association; USA: Everyday Democracy - Previously the Study Circles Resource Center etc.) (Larsson \& Nordvall, 2010). 


\section{Acta Educationis Generalis \\ volume 7, 2017, issue 2}

Concerning Hungary, learning circles have existed in different forms, with smaller or bigger differences. We can list here the registered cultural and public educational associations' activities, different clubs, study groups, non-registered reading circles or hobby circles based on common interests. For example, study groups were organized to actively acquire knowledge on a subject in the form of leisure-time activities. There were mineral collecting, stamp collecting, old coin collecting circles, as well as ornamental plant growing, pet breeding, photo and short film making, homeland knowing and astronomical circles. Even though there were not so many circles, generally they proved to be lasting. And what is more important, their members studied technical literature on the given subject, so they became experts in their interest groups. Still, they remained rarities in public education; they have never become as defining as the study circles in Sweden and other Northern-European countries (Maróti, 2014).

We can ask the question, whether all small groups in public education can be considered learning communities. The Adult Education and Training Encyclopaedia in Hungary defines learning groups in general as every group organized for learning. In a narrower interpretation, however, such a small group can be considered a learning group that works with direct guidance of a qualified leader or a leader without qualifications. According to Maróti (2014), learning foreign languages in groups can serve as an example for non-formal learning. Although the participants' work is characterized by activity and cooperation, their work is led by a language teacher and the members of the group adjust to the teacher. Such a language learning group is different from a learning community, there is a lack of self-guidance.

As long as we speak about language learners, opposite the traditional language learning groups, there is a different kind of practices and methodology that characterize the conversational clubs, for example. The foreign language (English, German, French etc.) conversational clubs, as their names suggest, are mainly directed to the development of oral skills in a foreign language, in a relaxed climate. If there is a language teacher present, they mainly have a facilitating, learning supporting role. Everyone can join, from beginners to advanced language learners; everybody takes part in the conversations according to their level. There is only one main rule; no one can say a word in Hungarian. The range of topics is wide. The topics of the conversations (e.g. culture, sport, actualities, work, free time) are defined by the participants together, they play and accepting an active role in the realization of their own learning process, although here again the members can change.

The above examples show that there is a methodologically significant difference between the educating groups and communities, as well as between the members of an audience of a lecture, participants of a language course and a self-motivated community. Compared to a group behaving as a simple unit, a community has an advantage - it is more than the amount of the activities of its members because the change of opinions in them and the activities supplementing each other remain even if the number of its members is reduced.

\section{Methodology projections of study circles}

In the text below, methodology projections of study circles are examined. Study circles can be viewed as learning- and participant-oriented small groups with self-educational forms of organization that are built on the division of work and cooperation of the participants, from selecting the learning materials and planning, through their utilization 


\section{Acta Educationis Generalis \\ volume 7, 2017, issue 2}

to evaluation of the achieved results. In study circles, everybody is important, the success of common work depends on the contribution of each member.

This paper is based on the Swedish traditions and experience (Kindström, 2010), we can outline the significant features of study circles as follows:

The basis for learning in a study circle comes from an interest in a common topic. We can speak about an open, free learning opportunity, the participation is voluntary, there is no input competence specified - at most, recommendations for applicants are given. Generally, it does not end with an exam and official papers, either. Experiences from the Swedish study circles shows that only some percentage of the participants hope to gain official papers. Study circles mainly build on the pleasure of learning and the curiosity towards the topic, as well as the need for communication and belonging to a community are among the significant motifs. In Sweden, for example, study circles almost exclusively represent the only learning possibility for the age group above 50, since other forms of adult education focus rather on younger adults (Bjerkaker, 2006; Campbell, 1998).

In an earlier research - "Society of circles", 63 participants were interviewed to get to know the reasons for their participation in study circles. The study was directed to explore the connection between the everyday life and study circle participation in a sophisticated way. During it, 44 different participation reasons were found, which were ranked into 6 meta-categories (Kindström, 2010):

1. Satisfying an interest: the most important arguments to join a study circle were interest and curiosity. Study circles were primarily built on the desire for knowledge corresponding to the needs and interests of the participants. Actualities that a wider society was interested were also among the reasons.

2. Knowledge: learning for knowledge that can be used in everyday life, that can be utilized in the world of work or even connected to different hobbies. Research on adult education confirmed that participants become more committed to learning if the "necessary advantages" for them appear during the learning process. They naturally depend on their attitude towards learning and also on the value of knowledge for the individual (learning for pleasure) (Kotler \& Keller, 2012).

3. Community: the social function was mentioned by almost all interviewed participants. Besides knowledge, good social relationships were also indicated as important. The driving force of participating in a community was the cooperation between its members and not the rivalry between them. The "necessary advantage" can occur in this form as well; besides the generally supposed ones (utilization in the world of work or everyday life etc.), it can even be a kind of communication need (for example belonging to a community).

These three meta-categories could be found in the majority of the persons interviewed. Other reasons can be found in the following categories:

4. Personal development: emphasizing its significance, its influence on increasing one's self-esteem.

5. A study circle as a democratic forum: a part of the participants emphasized the opportunity to tell and discuss their opinions.

6. A way of learning: emphasizing the freedom of choice and the absence of exams.

It was also stated in the study that the participation in a study circle had usually not only one, but more reasons, the participants joined them usually due to several reasons. 


\section{Acta Educationis Generalis \\ volume 7, 2017, issue 2}

As far as the composition of the members of study circles is concerned, we can usually talk about heterogeneous groups. The participants were different from the point of view of gender, age, qualifications, marital status as well as their workplace, and they had different preliminary knowledge and experience. The interest in the topic was the same. The number of persons in the groups should be neither too high nor too low. If a group has fewer than five members, the experience shows that it is hard to maintain a general conversation, if it is too big, then the cooperation and common responsibility inside the group can be damaged. Namely, the work inside the study circles is based on the active participation and cooperation of its members. The ideal number of the members in a learning group is between 8 and 10, so, every member of the group can be in a communicational relationship with the others and there is a possibility of exchanging opinions and experiences too.

Planning the work in a study circle and the formulation of the aims are jointly discussed by the participants, they approve and target them, and thus, an active involvement from the participants is indispensable. The participants can even change or modify the plan in a flexible way during the study circle work, since the learning plan is seen as a tool for learning. The members of the study circle are responsible for their own work and accomplish their learning objectives. It is also important that the work in the study circle should start from the experiences and knowledge of the participants and build on their preliminary knowledge and experiences.

The leader of the study circle is not a traditional leader, but they are rather the facilitator and the supporter of the participants. The leader is aware of the principles of group dynamics and supports the dialogue among the participants. As in the real life, in the study circles, there are people who do not hide their opinions while others are shy and quiet. The leader of the study circle strengthens the self-esteem of the participants, creates a relaxed climate, encourages cooperation and prevents rivalries.

The fact whether the expectations of the participants come to light before the start of the learning process has a significant impact on the success of the work in the study circle.

The experience from the Swedish study circles show that if the common work shifts to any end of the scale, namely if it becomes too school-like, that is, if the free exchange of opinions is replaced by orientation on curriculum and teaching (for example, the process becomes too controlled), or if the working climate becomes too free or jovial, it endangers the joint learning. The reason for this can be found in the weak motivation of the participants or too high expectations.

We can say that certain pillars of the learning-oriented approach (Kopp, 2013) are clearly reflect in the study circles - knowledge, learning support and the community stand in their centre.

\section{Study circles in the online learning environment}

In the continuation of our study, we focus on methodological projections of the study circles realized in the online learning environment.

Prior to the online learning environment, place and time were of determinative significance. The person who did not find partners of the same interest in his or her place of living or could not comply his or her free time with the other participants, had a not easy task.

With the emergence and booming development of informational technology means the possibilities of gaining knowledge widened. New technology reinterprets the feedback, 


\section{Acta Educationis Generalis \\ volume 7, 2017, issue 2}

interactive and reflective features of learning. Parallel to the spread of the broadband Internet and the interactive web 2.0 means, connectivism as the theory of network learning appeared (Verhagen, as cited in Bessenyei \& Szirbik, 2011).

George Siemens (2005) finds connectivism the learning theory of the digital era. According to Benedek, connectivism considers learning a process in which information exchange supported by informal, online means, organized into networks has a definitive role among the interchanges. Gaining knowledge is a process during which specialized interchanges are connected to information sources. Participation in networks, the access to information, software serving the interpretation of information and putting them into contexts give the possibility of a completely new, cooperating and self-educating learning. Such services are provided by, for example, community sites (Facebook, Google+), photo-sharing sites (Flickr), video-sharing sites (YouTube, Videa) and various blogs. Here we can list Wikipedia and other, freely editable information stores, Twitter, different link-sharing sites (LinkedIn, delicious) and forums, as well as online office applications (Google Docs), news sources (RSS), and online storage providers (Dropbox) (Benedek, 2013).

The expression online or virtual community is used in many senses in technical literature dealing with the topic and the standard language. "It can mean an Internet forum, a group of online videogame players, as well as a research team working on a common project. The examples also show that the online communities often exist not only in the cyber space but the online community can also replicate or "lengthen" our real relationships, and can mean relationships beyond, from which later even real personal relationships can be born" (Fejes, 2007, p. 32).

The essence of the online learning community can likewise be found in the interactions, group activities developing in the online environment, and a difference can be made in the group activities for example by the fact whether collaboration occurs or not.

In connectivism, cooperative and collaborative learning get an emphasized role. In our interpretation, cooperative learning means that group members help each other to reach the individual's learning objectives, while during collaborative learning, the group members support each other to reach the common learning objectives. During the cooperation, the participants divide the tasks among each other, and every group member is responsible for a certain piece of task. Collaboration is, however, such "building of knowledge" during which the division of work is spontaneous, depending on who can contribute with what to the joint work (Tóth, 2013). During cooperation, the "distributed roles" are fixed until the learning process ends, but in the process of collaboration, the roles can change even several times depending on who and with what kind of knowledge can contribute to the given working process (Dorner, 2007). So, collaborative learning can be understood as "a collaborative knowledge building process directed to solving a given problem, during which the participants share their theories connected to the solution of the problem and they also harmonize these" (Baba, as cited in Dorner, 2007, p. 303).

With the involvement of community sites (e.g. Google+, Facebook etc.), there is a new possibility of inspiring study circles - utilizing the power of communities and the possibilities given by network-based learning. Google+ and Facebook also give opportunities for asynchronous communication. For example, a closed Facebook group gives space for everyday communication or project-like tasks, and can efficiently support almost any kind of community activity. Each participant takes part in the 


\section{Acta Educationis Generalis \\ volume 7, 2017, issue 2}

learning process using his/her own Facebook profile, but the extent of information visible about the members can vary. There are participants whose profiles are public, complete, while others show only limited information. Google+ is at present the second biggest among the online communities in terms of the number of users (Ollé \& Lévai, 2013).

We can mention the initiative called Virtual University of Károly Eszterházy University as an example. Those interested can choose among many topics based on their interests. Certain courses can be realized in different learning environments (e.g. Moodle, Google+, Facebook group, etc.). Some courses have credit values, these are mainly for higher education students, other courses offer the opportunity to "study for pleasure" free and open learning.

Those courses are in the centre of our attention, in which some of the features of study circles and certain pillars of the learning-oriented approach are reflected.

The period of the courses is predetermined, one can apply after preliminary registration, and, usually, there is no possibility for joining after they started. The courses are generally built on an activity-orientated network work. For its successful accomplishment, activity and intensive and initiative communication between the participants are required. The initiative builds on differentiated marketing activities as for the addressed target group: it tries to address more segments by building on the "necessary advantages" of the participants.

Certain courses can be a great form of the completion of the formal school studies for primary school, secondary school or even higher education students. Moreover, they offer learning possibilities for those wishing to refresh, renew their knowledge, for people open and interested in life matters, for those working in changing shifts, or some special target groups (mothers with babies, pensioners, those living geographically far away, those wishing to study in Hungarian, those having limited opportunities for moving, etc.).

Courses functioning as learning communities offer such learning situations which the participants can actively join and act in, they can bring creative ideas and ask questions about a topic. The tasks are characterized by diversity and colourfulness. The course leader is, in the case of the learning circle-oriented courses, present rather as a facilitator of the participants - they create the opportunity to study both individually and together for the participants, and support the dialogues among the participants. In every phase of the learning process (planning, organization, realization, and evaluation), the learning activity of the participants comes into focus, where the participants, too, can influence certain activities and the space for learning.

During the joint online work, there is the possibility to share and store information in an organized way and to use many kinds of communication surfaces (Uden, et al., 2015). Brainstorming of ideas in connection with a topic can be realized in the online form, too, with the help of sites that can be edited together, to which videos, photos, links and files can be added, for example with Padlet or Lino web applications.

Community learning to be realized in an online learning environment can well be supplemented and supported also by the following:

- Google Drive public or private storage - for sharing and storing files;

- Google document to be shared with other people - interactive Word document for common note-taking, brainstorming of ideas;

- $\quad$ Google Slides - give the possibility of jointly edited PowerPoint slide shows; 


\section{Acta Educationis Generalis \\ volume 7, 2017, issue 2}

- Google Calendar - different events can be created to which invitations can be sent;

- Google+ community site - generating community content (sharing and commenting on documents in an open or closed community, sharing of video and sound files, etc.);

- $\quad$ Mind-mapping software;

- Skype - synchronous communication: conference call, video call, chat etc.

\section{Conclusion}

The above examples show that the online learning environment can be well utilized for community learning. It is predicted that the role of learning communities is going to grow. Members of virtual communities established around a common interest are going to move more easily into the info-communicational space than the present generation. Though the practical application of connectivism is more demanding in the formal school environment, experiences show that in a non-formal learning environment, where the pillars of learning-oriented approach can be more visible, it can be well utilized. In the online learning environment, learning requires a specific type of behaviour different from classroom situations as the individual's responsibility is bigger than in the traditional educational environment and self-regulation gets an even bigger role as the participants are not physically present (Noesgaard \& Ørngreen, 2015; Nehme, 2010).

\section{References}

Baba, S. (2005). The dynamics of study circles: Some reflections on ABIM's collaborative learning system. Malaysia: Academy for Civilizational Studies. Retrieved from: http://irep.iium.edu.my/7540/1/The_dynamics_of_study_circles. pdf

Benedek, A. (2013). Új pedagógiai paradigma - 2.0: Tételek a digitális tanulásról. In A. Benedek (Ed), Digitális pedagógia 2.0 (pp. 15-51). Budapest: Typotex Kiadó.

Bessenyei, I., \& Szirbik, G. (2011). Hálózatok, társas tudás, konnektivizmus. Oktatás Informatika, 1-2, 20-30.

Bjerkaker, S. (2006). The Study Circle: For Learning and Democracy. Convergence, $39(2-3), 49-60$.

Biggs, J., \& Tang, C. (2007). Teaching for Quality Learning at University. Open University Press. Retrieved from http://bit.ly/2mWn469

Campbell, S. L. (1998). A Guide for Training Study Circle Facilitators. Study Circles Resource Center, a project of the Topsfield Foundation, Inc. Retrieved from http://www.awcnet.org/documents/tools_studycirclefacilitatorsguide.pdf

Dorner, H. (2007). Kollaborativ tudásépités számitógéppel segitett tanulási környezetben - A tudásépitö interakciók elemzése. MultiMédia az Oktatásban 2007 conference. Budapesti Müszaki Főiskola. Retrieved from http://conf.uni-obuda.hu/multimedia 2007/55_DornerHelga.pdf

Fejes, J. B. (2007). Online tanulóközösségek. Iskolakultúra, 4, 32-37.

Forray R. K., \& Juhász, E. (2008). Az autonóm tanulás és az oktatás rendszere. Új Pedagógiai Szemle, 58(3), 62-68.

Harangi, L. (2010). A művelődési önszerveződés svéd modellje. Szín, 15(1), 32-36.

Kindström, C. (2010). A tanulókörök módszerének a bemutatása. Szentendre: Budapest Környéki Népföiskolai Szövetség. 


\section{Acta Educationis Generalis \\ volume 7, 2017, issue 2}

Kopp, E. (2013). Tanulásközpontú programfejlesztés. Felsőoktatási Mühely, 2, 39-56.

Kotler, P., \& Keller, K. L. (2012). Marketing management. Prentice Hall. Retrieved from: http://bit.ly/1xXKzJq

Larsson, S., \& Nordvall, H. (2010). Study Circles in Sweden. An Overview with a Bibliography of International Literature. Linköping University Electronic Press. Retrieved from http://liu.diva-portal.org/smash/get/diva2:328351/FULLTEXT01

Maróti, A. (2014). Közösségi a közmüvelődés? Kulturális Szemle, 1, 26-32.

Nehme, M. (2010). E-Learning and Students' Motivation. Legal Education Review, 20(1-2), 223-239.

Noesgaard, S. S., \& Ørngreen, R. (2015). The Effectiveness of E-Learning: An Explorative and Integrative Review of the Definitions, Methodologies and Factors that Promote e-Learning Effectiveness. Electronic Journal of e-Learning, 13(4), 278-290.

Ollé, J., \& Lévai, D. (2013). A XXI. század oktatástechnológiája I. Eger: EKF.

Siemens, G. (2005). Connectivism: A Learning Theory for the Digital Age. Instructional Technology and Distance Learning, 2(1). Retrieved from http://www.itdl.org/ journal/jan_05/article01.htm

Uden, L., Liberona, D., \& Welzer, T. (Eds.). (2015). Learning Technology for Education in Cloud. Springer.

Tóth, P. (2013). Tanulási teljesítmény mérése online környezetben. In A. Benedek (Ed.), Digitális pedagógia 2.0 (pp. 220-271). Budapest: Typotex Kiadó.

Verhagen, P. (2006). Connectivism: a new learning theory? Retrieved from http://elearning.surf.nl/e-learning/english/3793 